\title{
Depresi, Kecemasan, dan Stres Remaja selama Pandemi Covid-19.
}

\author{
Swastika Tiara Pertiwi ${ }^{1}$, Marisa Fransiska Moeliono ${ }^{1}$, Lenny Kendhawati ${ }^{1}$ \\ ${ }^{1}$ Program Studi Magister Profesi Psikologi, Fakultas Psikologi, Universitas Padjadjaran \\ Jl. Raya Bandung-Sumedang KM 21, Jatinangor - Sumedang, Jawa Barat, 45363 \\ Penulis untuk Korespondensi/E-mail: swastikatiarapertiwi@gmail.com
}

\begin{abstract}
Adolescent are quite vulnerable to experience negative psychological conditions such as depression, anxiety, and stress. The existence of the Covid-19 pandemic has led to policies such as social distancing that restrict adolescent so they need to adapt to be able to carry out their daily activities and carry out their developmental tasks. This study aims to determine the prevalence of negative psychological conditions in adolescent, such as depression, anxiety, and stress during the Covid-19 Pandemic. This research is a quantitative descriptive approach with a cross-sectional design. This research was conducted during August 2020 on 647 adolescents aged 14-18 years in Bandung. The measuring instrument used was the DASS-42 which was done online by participants. The reliability of DASS-42 in this study has an alpha coefficient of 0.955 . The results showed that the most negative psychological condition experienced by adolescent during the Covid-19 Pandemic was anxiety, which was found in $58,74 \%$ of adolescent. In addition, 32,15\% of adolescent experienced depression and 34,7\% of adolescent experienced stress during the Covid-19 Pandemic. The prevalence of negative psychological conditions such as depression, anxiety and stress are more experienced by girls than boys.
\end{abstract}

Abstrak - Remaja cukup rentan mengalami kondisi psikologis yang negatif seperti depresi, kecemasan dan stress. Pandemi Covid-19 yang terjadi menyebabkan adanya kebijakan seperti social distancing yang membatasi remaja sehingga remaja perlu beradaptasi kembali untuk dapat menjalani kegiatan sehari-hari maupun menjalani tugas-tugas perkembangannya. Penelitian ini bertujuan untuk mengetahui prevalensi kondisi psikologis yang negatif pada remaja yakni depresi, kecemasan, dan stress selama Pandemi Covid-19. Penelitian ini merupakan penelitian kuantitatif menggunakan desain cross-sectional. Penelitian ini dilakukan selama Bulan Agustus 2020 terhadap 647 remaja berusia 14-18 tahun di Kota Bandung. Alat ukur yang digunakan adalah DASS-42 yang dikerjakan oleh partisipan secara daring. Reliabilitas DASS-42 pada penelitian ini memiliki koefisien alpha sebesar 0,955. Hasil penelitian menunjukkan kondisi psikologis negatif yang paling banyak dialami oleh remaja selama Pandemi Covid-19 adalah kecemasan yang dirasakan oleh 58,74\% remaja. Disamping itu, terdapat $32,15 \%$ remaja yang mengalami depresi dan $34,7 \%$ remaja mengalami stress selama Pandemi Covid19. Prevalensi kondisi psikologis negatif seperti depresi, kecemasan dan stress lebih banyak dialami oleh remaja perempuan dibandingkan dengan remaja laki-laki.

Keywords - Depression, Anxiety, Stress, Adolescent, Covid-19.

\section{PENDAHULUAN}

$\mathrm{C}$ ovid-19 mulai diumumkan masuk ke Indonesia sejak Maret 2020 [1]. Sejak saat itu, pemerintah pusat maupun daerah membuat kebijakan-kebijakan untuk menanggulangi penyebaran Covid-19. Salah satu contohnya, Gubenur Jawa Barat membuat beberapa kebijakan yakni Pembatasan Sosial Skala Besar (PSBB) dan Adaptasi Kebiasaan Baru (AKB)[2]. Konsep social distancing juga diterapkan selama pandemi Covid19. Di Indonesia, social distancing diatur dalam UU No. 6 Tahun 2018 pasal 59 dan pasal 60. Pada pasal 59 ayat 3 dikatakan bahwa social distancing dilakukan dalam bentuk meliburkan tempat kerja, meliburkan kegiatan pada tempat-tempat 
keagamaan, pembatasan kegiatan di fasilitas umum, serta meliburkan sekolah [3].

Dampak negatif dari adanya Pandemi Covid-19 terhadap individu adalah menyebabkan krisis psikologis [4]. Pandemi Covid -19 menyebabkan perubahan psikologis yang dipicu oleh ketakutan, depresi, kecemasan dan perasaan insecure [5]. Di China, dilaporkan bahwa terdapat lebih dari separuh jumlah partisipan penelitian selama fase pandemi awal mengalami dampak psikologis seperti depresi, kecemasan dan stress pada kategori sedang hingga berat [6]. Dampak buruk dari Covid19 yang dirasakan baik oleh pasien maupun masyarakat luar secara garis besar adalah depresi, kecemasan dan juga stress [7].

Menurut American Psychological Association (APA), depresi lebih dari sekedar kesedihan. Individu yang mengalami depresi mengalami kurangnya minat dalam kegiatan sehari-harinya, mengalami penurunan dan kenaikan berat badan yang signifikan, insomnia atau tidur berlebihan, kekurangan energi, sulit berkonsentrasi dan memiliki perasaan bersalah atau tidak berharga secara berlebihan [8]. Menurut APA, kecemasan merupakan keadaan emosi yang ditandai dengan adanya perasaan tegang, pikiran khawatir dan adanya perubahan fisik seperti tekanan darah yang meningkat [9]. Kecemasan menurut Sarwono adalah perasaan takut yang objeknya tidak jelas juga tidak jelas alasannya [10]. Stress menurut Lazarus dan Folkman merupakan hubungan antara individu dengan lingkungannya yang dinilai oleh individu sebagai tuntutan maupun ketidakmampuannya menghadapi situasi yang mengancam atau membahayakan diri [11].

Pada usia remaja, individu mengalami transisi dari kehidupan anak-anak menuju kehidupan dewasa. Pada periode ini individu banyak mengalami perkembangan pesat baik secara biologis, psikologis, kognitif, maupun secara sosioemosional [12]. Oleh karena itu, remaja banyak melakukan penyesuaian terhadap lingkungannya. Remaja merupakan tahapan usia yang cukup rentan secara emosional. American Psychological Association (APA) melakukan survei berkala terkait distress pada masyarakat di Amerika. Sejak 2013, remaja telah dilaporkan memiliki tingkat distress yang lebih tinggi dibandingkan dengan orang dewasa [13].

Dampak pandemi Covid-19 tidak dapat dihindari terjadi pada remaja. Survei yang dilakukan oleh
Himpunan Psikologi Indonesia (HIMPSI) menyatakan bahwa remaja atau anak muda di bawah usia 21 tahun mengalami tekanan psikologis yang lebih berat dibandingkan usia lainnya selama Pandemi Covid-19 [14]. Penelitian di China terhadap anak dan remaja selama pandemi Covid19 menghasilkan data bahwa terdapat kenaikan tingkat Psychological Distress dalam bentuk perasaan takut, depresi dan cemas jika dibandingkan dari sebelum pandemi Covid-19 [15].

Belum terdapat penelitian di Indonesia yang menggambarkan kondisi psikologis negatif dalam bentuk depresi, kecemasan, dan stress remaja selama Pandemi Covid-19. Dengan demikian, penelitian ini bertujuan untuk memberi gambaran mengenai prevalensi kondisi psikologis negatif yakni depresi, kecemasan, dan stress yang dialami remaja selama Pandemi Covid-19.

\section{METODE}

Penelitian ini merupakan penelitian deskriptif dengan menggunakan desain cross-sectional. Metode penarikan sampel pada penelitian ini menggunakan teknik respondent driven sampling terhadap 647 remaja dengan rentang usia 14-18 tahun di Kota Bandung. Pengumpulan data penelitian dilakukan selama bulan Agustus 2020 dengan menggunakan media google form dan dilakukan secara daring. Partisipan mengisi angket/kuesioner DASS-42 yang dilampirkan di dalam link google form yang disebarkan melalui group chat Whatsapp, media sosial Instagram dan Twitter.

Kuesioner DASS-42 yang diisi oleh partisipan berjumlah 42 item, dimana 14 item mengukur tingkat depresi, 14 item mengukur kecemasan dan sebanyak 14 item mengukur tingkat stres remaja yang dihayati oleh remaja selama pandemi. Kuesioner yang digunakan dalam penelitian ini merupakan kuesioner DASS-42 yang disusun oleh Lovibond (1995) dan telah diadaptasi ke Bahasa Indonesia oleh Damanik (2008). DASS-42 dalam versi Bahasa Indonesia merupakan alat ukur yang telah valid berdasarkan pengujian internal consistecy dan juga reliabel karena memiliki koefisien alpha sebesar 0,9843 [17]. Untuk masingmasing skala DASS-42 pada penelitian ini, reliabilitas dari skala depresi memiliki koefisien alpha sebesar 0,921. Skala kecemasan memiliki koefisien alpha sebesar 0,857 dan Skala stress memiliki koefisien alpha sebesar 0,899. Reliabilitas 
alat ukur DASS-42 secara keseluruhan koefisien alpha sebesar 0,955.

Pada kuesioner DASS-42, partisipan memilih salah satu dari empat pilihan jawaban dalam bentuk skala Likert. Adapun pilihan tersebut yakni; Pilihan 0: Tidak sesuai dengan saya sama sekali, atau tidak pernah. Pilihan 1: Sesuai dengan saya sampai tingkat tertentu, atau kadang-kadang. Pilihan 2: Sesuai dengan saya sampai batas yang dapat dipertimbangkan, atau lumayan sering. Pilihan 3: Sangat sesuai dengan saya, atau sering sekali. Selanjutnya, skor dari masing-masing sub- skala dijumlahkan dan dibandingkan dengan norma yang sudah ada untuk mendapatkan gambaran mengenai kondisi psikologis negatif seperti depresi, kecemasan, dan stress individu apakah tergolong pada kategori normal, mild, moderate, severe, atau extremely severe. [17]

Peneliti ingin mengetahui apakah terdapat perbedaan yang signifikan antara remaja perempuan dan remaja laki-laki untuk masingmasing kondisi psikologi negatif selama pandemi Covid-19. Oleh karena itu, sebelum melakukan Uji Beda dilakukan Uji Normalitas untuk mengetahui apakah data yang sudah dikumpulkan berdistribusi normal. Uji beda yang dilakukan menggunakan Mann-Whitney karena data yang dikumpulkan pada penelitian ini tidak berdistribusi normal dengan signifikansi 0,00 pada masing-masing skala.

\section{HASIL DAN PEMBAHASAN}

Berikut di dalam Tabel 1 dipaparkan mengenai karakteristik partisipan dalam penelitian ini.

Tabel 1. Karakteristik Partisipan

\begin{tabular}{lll}
\hline Karakteristik & F & \% \\
\hline Usia & & \\
\hline 14 Tahun & 5 & 3,86 \\
15 Tahun & 238 & 36,7 \\
16 Tahun & 222 & 34,3 \\
17 Tahun & 143 & 22,1 \\
18 Tahun & 19 & 2,93 \\
\hline Total & $\mathbf{6 4 7}$ & $\mathbf{1 0 0}$ \\
\hline Jenis Kelamin & & \\
\hline Laki-laki & 221 & 34,2 \\
Perempuan & 426 & 65,8 \\
\hline Total & $\mathbf{6 4 7}$ & $\mathbf{1 0 0}$ \\
\hline
\end{tabular}

Berdasarkan Tabel 1, diketahui bahwa sebanyak lebih dari setengah partisipan berjenis kelamin perempuan yakni 426 orang $(65,8 \%)$ dan laki-laki berjumlah 221 orang $(34,2 \%)$. Pada penyebaran usia, partisipan didominasi remaja usia 15 tahun sebanyak 238 orang $(36,7 \%)$ dan remaja usia 16 tahun $(34,3 \%)$.

Tabel 2. Gambaran Kondisi DAS Remaja secara Umum

\begin{tabular}{llll}
\hline Variabel & Kategori & \multicolumn{2}{l}{ Jumlah } \\
\cline { 3 - 4 } & & $\mathbf{N}$ & $\mathbf{\%}$ \\
\hline Depresi & Normal & 439 & 67,85 \\
& Mild & 79 & 12,21 \\
& Moderate & 80 & 12,36 \\
& Severe & 29 & 4,48 \\
& Extremely & 20 & 3,1 \\
& Severe & & \\
\hline Kecemasan & Normal & 267 & 41,26 \\
& Mild & 86 & 13,3 \\
& Moderate & 151 & 23,33 \\
& Severe & 81 & 12,51 \\
& Extremely & 62 & 9,6 \\
& Severe & & \\
\hline Stress & Normal & 424 & 65,53 \\
& Mild & 88 & 13,6 \\
& Moderate & 83 & 12,82 \\
& Severe & 40 & 6,19 \\
& Extremely & 12 & 1,86 \\
& Severe & & \\
\hline
\end{tabular}

Hasil pemeriksaan psikologis menggunakan DASS42 menunjukkan bahwa sebanyak $67,85 \%$ remaja memiliki tingkat depresi pada kategori normal atau tidak mengalami depresi (Tabel 2). Dari hasil penelitian, diperoleh data bahwa sebanyak $32,15 \%$ remaja mengalami depresi dengan kategori yang berbeda-beda dari mild hingga extremely severe. Adanya penerapan social distancing membuat masyarakat banyak mengisolasi diri di rumah, melakukan segala aktivitas termasuk sekolah dan bekerja dari rumah. Dampak jangka panjang dari isolasi sosial bagi anak dan remaja adalah mereka dapat mengalami depresi [18]. Hal tersebut patut diperhatikan dimana dampak jangka panjang dari isolasi diri remaja di rumah dapat menyebabkan depresi pada beberapa tahun yang akan datang.

Remaja laki-laki terlihat berada pada tingkat depresi yang normal atau tidak mengalami depresi dengan presentase $74,7 \%$, sedangkan terdapat 64,3\% remaja perempuan memiliki kondisi depresi yang berada pada taraf normal atau tidak mengalami depresi. Pada remaja yang mengalami depresi baik pada kategori mild, moderate, severe maupun extremely severe remaja perempuan menempati presentase yang lebih banyak dibandingkan remaja laki-laki (Tabel 3). Berdasarkan hasil penelitian, diperoleh data pada masing-masing kategori pada kondisi depresi, anxiety dan stress, perempuan memiliki presentase lebih besar dibandingkan laki-laki (Tabel 3). Hal ini sejalan dengan beberapa penelitian sebelumnya. 
Dilansir menurut Cyranowski dan yang lainnya, Prevalensi depresi berat lebih tinggi pada perempuan dibandingkan laki-laki [19]. Penelitian lainnya dilakukan oleh Hatkin [19] menyebutkan bahwa remaja perempuan mengalami lebih banyak stressor baik subjektif maupun objektif dibandingkan laki-laki. Hal tersebut yang memediasi peningkatan prevalensi depresi pada remaja perempuan dibandingkan dengan remaja laki-laki.

Tabel 3. Gambaran DAS berdasarkan Jenis kelamin

\begin{tabular}{llllll}
\hline Variabel & Kategori & \multicolumn{2}{l}{$\begin{array}{l}\text { Laki-laki } \\
(\mathbf{N = 2 2 1})\end{array}$} & \multicolumn{2}{l}{$\begin{array}{l}\text { Perempuan } \\
(\mathbf{N}=\mathbf{4 2 6})\end{array}$} \\
\cline { 3 - 6 } Depresi & Normal & 165 & 74,7 & $\mathbf{N}$ & $\mathbf{\%}$ \\
& Mild & 27 & 12,21 & 52 & 64,3 \\
& Moderate & 24 & 10,85 & 56 & 13,2 \\
& Severe & 1 & 0,45 & 28 & 6,6 \\
& Extremely & 4 & 1,8 & 16 & 3,76 \\
& Severe & & & & \\
\hline Kecemasan & Normal & 115 & 52,03 & 152 & 35,68 \\
& Mild & 29 & 13,12 & 57 & 13,39 \\
& Moderate & 47 & 21,27 & 104 & 24,41 \\
& Severe & 23 & 10,5 & 58 & 13,61 \\
& Extremely & 7 & 3,17 & 55 & 12,91 \\
& Severe & & & & \\
\hline Stress & Normal & 163 & 73,76 & 261 & 61,26 \\
& Mild & 27 & 12,21 & 61 & 14,32 \\
& Moderate & 20 & 9,04 & 63 & 14,79 \\
& Severe & 8 & 3,61 & 32 & 7,52 \\
& Extremely & 3 & 1,36 & 9 & 2,11 \\
& Severe & & & & \\
\hline & & & & &
\end{tabular}

Sebagian besar remaja $(58,7 \%)$ mengalami kecemasan. Sebanyak 23,33\% remaja mengalami kecemasan pada kategori moderate. Diikuti dengan 13,3\% remaja dengan kecemasan kategori mild, $12,51 \%$ pada kategori severe dan sebanyak 9,6\% remaja pada kategori extremely severe (Tabel 2). Hal ini sejalan dengan penelitian yang dilakukan oleh Fitria [20] dimana sebagian besar partisipan penelitian remaja yakni sebanyak $54 \%$ mengalami kecemasan selama Pandemi Covid-19. Kecemasan yang dialami remaja selama Pandemi Covid-19 kemungkinan disebabkan karena remaja kekurangan pengetahuan terkait kondisi pandemi ini [21].

Remaja laki-laki dengan kecemasan kategori normal memiliki presentase 52,3\% yakni lebih banyak dibandingkan remaja perempuan dengan presentase $35,68 \%$. Remaja perempuan menempati presentase lebih tinggi pada masing-masing kategori kecemasan baik kategori mild, moderate, severe dan extremely severe (Tabel 3). Hal ini sejalan dengan prevalensi gangguan kecemasan yang lebih banyak presentasenya dialami oleh perempuan. Pada sepanjang rentang usia untuk gangguan kecemasan menyeluruh diperoleh prevalensi bahwa lebih tinggi pada wanita 6,6\% dibandingkan $3,6 \%$ pada pria yang mengalaminya, hal tersebut mulai muncul pada pertengahan masa remaja [19].

Sebanyak $65,53 \%$ atau sebagian besar remaja memiliki tingkat stress pada kategori normal selama Pandemi Covid-19. (Tabel 2). Sebanyak $34,47 \%$ remaja mengalami stress dengan kategori beragam dari mild hingga extremely severe. Prevalensi stress remaja selama Pandemi Covid-19 pada penelitian ini memiliki presentase yang lebih tinggi dibandingkan populasi penelitian di China yakni $29,29 \%$, di India yakni 11,6\% dan di Italia yakni sebesar $14,6 \%$ selama pandemi Covid-19 [22]. Salah satu penyebab tingkat stress remaja selama pandemi adalah karena remaja mengalami kesulitan ketika harus belajar di rumah. Remaja beranggapan bahwa pembelajaran daring ini kurang efektif untuk dilaksanakan [23].

Sebanyak $73,76 \%$ remaja laki-laki memiliki tingkat stress yang berada pada kategori normal, presentase tersebut lebih banyak dibandingkan remaja perempuan dengan presentase $61,26 \%$ yang berada pada kategori normal (Tabel 3). Remaja yang mengalami stress sebanyak $34,7 \%$ dari berbagai kategori dari mild. Serupa dengan kondisi psikologis lain yang diukur, remaja perempuan cenderung lebih banyak megalami stress yakni sebanyak 38,74\% dibandingkan laki-laki yakni $26,24 \%$.

Tabel 4. Uji Beda Mann-Whitney Jenis Kelamin dengan DAS

\begin{tabular}{|c|c|c|c|c|}
\hline Variabel & $\begin{array}{c}\text { Mann- } \\
\text { Whitne } \\
y\end{array}$ & $\mathbf{Z}$ & Sig & Ket \\
\hline Depresi & $\begin{array}{c}40012,0 \\
00\end{array}$ & $-3,137$ & 0,02 & $\begin{array}{l}\text { Terdapat } \\
\text { perbedaan } \\
\text { signifikan }\end{array}$ \\
\hline Kecemasan & $\begin{array}{c}35920,0 \\
00\end{array}$ & $-4,954$ & 0,00 & $\begin{array}{l}\text { Terdapat } \\
\text { perbedaan } \\
\text { signifikan }\end{array}$ \\
\hline Stress & $\begin{array}{c}39311,0 \\
00\end{array}$ & $-3,446$ & 0,01 & $\begin{array}{l}\text { Terdapat } \\
\text { perbedaan } \\
\text { signifikan }\end{array}$ \\
\hline
\end{tabular}

Saat dilakukan uji normalitas, data pada penelitian ini memiliki signifikansi 0,00 pada masing-masing hasil dari skala depresi, kecemasan maupun stress sehingga dapat dikatakan bahwa data tidak 
berdistribusi normal. Peneliti menggunakan uji beda Mann-Whitney untuk melihat signifikansi perbedaan kondisi Depresi, Kecemasan dan Stress pada remaja laki-laki dan remaja perempuan. Berdasarkan Tabel 4, dapat dilihat bahwa terdapat perbedaan signifikan antara remaja laki-laki dan remaja perempuan pada masing-masing kondisi psikologis yang negatif yakni depresi, kecemasan dan stress dimana perempuan memiliki persentase lebih banyak pada masing-masing kondisi tersebut dalam kategori mild, moderate, severe dan extremely severe (Tabel 3).

\section{KESIMPULAN}

Berdasarkan penelitian yang dilakukan terhadap 647 remaja di Kota Bandung, dapat ditarik kesimpulan bahwa kecemasan merupakan kondisi psikologis negatif yang paling banyak dialami oleh remaja. Prevalensi pada masing-masing kondisi psikologis negatif lebih banyak dialami oleh remaja perempuan dibandingkan dengan remaja laki-laki.

Saran penelitian yang dapat dilakukan selanjutnya adalah penelitian untuk mengidentifikasi faktorfaktor yang berkontribusi terhadap kecemasan remaja selama Pandemi Covid-19, khususnya pada remaja perempuan.

\section{UCAPAN TERIMA KASIH}

Peneliti mengucap syukur dan terimakasih kepada Allah Swt karena diberi kelancaran dalam proses penyelesaian penelitian ini. Peneliti mengucapkan terimakasih kepada Siswa SMP dan SMA di Kota Bandung yang bersedia menjadi partisipan dan bersedia mengisi kuesioner secara daring, juga kepada pihak-pihak yang membantu peneliti menyebarkan kuesioner daring. Akhir kata, peneliti mengucapkan terimakasih kepada Dr. Fitri Ariyanti Abidin, M.Psi., Psikolog yang telah meluangkan waktu dan tenaga untuk membantu me-review artikel penelitian ini.

\section{REFERENSI}

[1] Kompas, Diumumkan Awal Maret, Ahli: Virus Corona Masuk Indonesia dari Januari, https://www.kompas.com/sains/read/2020/05/1 1/130600623/diumumkan-awal-maret-ahli-virus-corona-masuk-indonesia-dari-januari , 2020.(Diakses pada 26 Oktober 2020)

[2] Suara.com, Kebijakan Ridwan Kamil atas
Covid-19 hingga Adaptasi Kebiasaan Baru, https://yoursay.suara.com/news/2020/06/17/18 4224/kebijakan-ridwan-kamil-atas-covid-19hingga-adaptasi-kebiasaan-baru, 2020. (Diakses pad 26 Oktober 2020)

[3] Presiden Republik Indonesia, UU Nomor 6 Tahun 2018. 2018.

[4] Y. T. Xiang et al., "Timely mental health care for the 2019 novel coronavirus outbreak is urgently needed," The Lancet Psychiatry, vol. 7, no. 3, pp. 228-229. 2020. doi: 10.1016/S2215-0366(20)30046-8.

[5] J. Zhanga et al., "The Differential Psychological Distress of Population Affected by The Covid-19 Pandemic", Brain, Behavior and Immunity $87 \mathrm{pp} 49-50.2020$.

[6] C. Wang et al., "Immediate Psychological Responses and Associated Factors during the Initial Stage of the 2019 Coronavirus Disease ( COVID-19 ) Epidemic among the General Population in China,". International Journal of Environmental Research and Public Health. 2019.

[7] Humas UNS, Dampak Covid-19 menurut Psikolog UNS, https://uns.ac.id/id/unsupdate/dampak-covid-19-menurut-psikologuns.html, 2020. (Diakses pada 26 Oktober 2020)

[8] APA, Depression, APA, https://www.apa.org/topics/depression (Diakses pada 27 Oktober 2020)

[9] APA, Anxiety, APA. https://www.apa.org/topics/anxiety\#: :text= (Diakses pada 27 Oktober 2020)

[10] Sarwono. S W, Psikologi Remaja, Revisi. Depok: Rajagrafindo Persada, 2010.

[11] R. S. Lazarus and S. Folkman, Stress, Appraisal, and Coping. New York USA: Springer Publishing Company, 1984.

[12] Papalia, E. Diane, Olds, W. Sally, Feldman, and D. Ruth, Human Development Perkembangan Manusia. Jakarta: Salemba Humanika, 2009.

[13] S. Bethune, Teen stress rivals that of adults, APA,https://www.apa.org/monitor/2014/04/tee n-stress, 2014. (Diakses pada 26 Oktober 2020)

[14] ABC Australia, Dampak Psikologi Virus Corona di Indonesia dan Cara Mengatasinya, Viva,https://www.viva.co.id/berita/nasional/12 75412-dampak-psikologi-virus-corona-diindonesia-dan-cara-mengatasinya,

2020. (Diakses pada 27 Oktober 2020)

[15] L. Duan et al., "An investigation of mental health status of children and adolescents in 
china during the outbreak of COVID-19", $J$. Affect. Disord., vol. 275, no. July, pp. 112118, 2020, doi: 10.1016/j.jad.2020.06.029.

[16] Priyono, Metode Penelitian Kuantitatif. Sidoarjo: Zifatama Publishing, 2016.

[17] Damanik. E.D, DASS, UNSW, http://www2.psy.unsw.edu.au/dass/Indonesian/ Damanik , 2008. (Diakses pada 26 Oktober 2020)

[18] M. E. Loades et al., "Rapid Systematic Review: The Impact of Social Isolation and Loneliness on the Mental Health of Children and Adolescents in the Context of COVID19". American Academy of Child \& Adolescent Psychiatry, 2020.

[19] M. Altemus, N. Sarvaiya, and C. Neill Epperson, "Sex differences in anxiety and depression clinical perspectives". Front. Neuroendocrinol., vol. 35, no. 3, pp. 320-330, 2014. doi: 10.1016/j.yfrne.2014.05.004.
[20] L. Fitria and I. Ifdil, "Kecemasan remaja pada masa pandemi Covid -19", Jurnal Educatio vol. 6, no. 1, pp. 5-8, 2020.

[21] A. Purwanto et al., "Studi Eksploratif Dampak Pandemi COVID-19 Terhadap Proses Pembelajaran Online di Sekolah Dasar", EduPsyCouns Journal vol. 2, pp. 1-12, 2020.

[22] R. Lakhan, A. Agrawal, and M. Sharma, "Prevalence of Depression, Anxiety, and Stress during COVID-19 Pandemic", $J$ Neurosci. Rural Pract., pp. 1-7, 2020. doi: 10.1055/s-0040-1716442.

[23] S. Sekar, D. Ananda, dan N. C. Apsari, Prosiding Penelitian \& Pengabdian Kepada Masyarakat "Mengatasi Stress pada Remaja saat Pandemi Covid-19 dengan Teknik Self Talk", Vol 7 No:2, halaman 248-256, 2020. 